\title{
Pengaruh Penambahan Laurat dan Glisin terhadap Nilai Warna dan Kadar Sitrinin Angkak
}

\author{
Effect of Lauric and Glycine on Color Value and Citrinin of Angkak \\ Susana Ristiarini ${ }^{1}$, Muhammad Nur Cahyantoํㄹ ${ }^{2}$ Jaka Widada ${ }^{3}$, Endang Sutriswati Rahayu ${ }^{2 *}$ \\ ${ }^{1}$ Fakuktas Teknologi Pertanian, Universitas Katolik Widya Mandala Surabaya, \\ Jl. Dinoyo 42, Surabaya 60265, Indonesia \\ 2Departemen Teknologi Pangan dan Hasil Pertanian, Fakultas Teknologi Pertanian, \\ Universitas Gadjah Mada, Jl. Flora No. 1, Bulaksumur, Yogyakarta 55281, Indonesia \\ ${ }^{3}$ Fakultas Pertanian, Universitas Gadjah Mada, Jl. Flora, Bulaksumur, Yogyakarta 55281, Indonesia \\ *Email: endangsrahayu@ugm.ac.id
}

Tanggal submisi: 28 Juli 2017; Tanggal penerimaan: 31 Agustus 2018

\begin{abstract}
ABSTRAK
Angkak yang umum digunakan untuk pewarna dan penambah cita rasa dalam masakan oriental merupakan hasil fermentasi Monascus purpureus pada media beras tanak. Selain menghasilkan pigmen, Monascus purpureus juga menghasilkan mikotoksin, sitrinin, yang bersifat hepato-nephrotoksik. Biosintesis pigmen dan sitrinin melalui jalur poliketida sintase yang kemudian bercabang untuk membentuk pigmen atau sitrinin. Asam lemak dan asam amino diketahui sebagai prekursor pembentuk pigmen merah dalam jalur biosintesisnya. Penelitian ini bertujuan untuk mengetahui pengaruh penambahan asam lemak laurat dan asam amino glisin pada substrat beras tanak terhadap karakteristik warna dan kadar sitrinin angkak oleh M. purpureus JK9A. Asam lemak laurat yang ditambahkan adalah $0,5 \%$ dan glisin sebesar $1 \%$ (b/b). Fermentasi dilakukan selama 14 hari dan setiap dua hari dilakukan pengamatan terhadap kadar padatan produk fermentasi, $\mathrm{pH}$, jumlah sel, warna, pigmen yang terlarut dalam air. Kadar sitrinin diuji pada akhir masa fermentasi (hari ke 14). Hasil penelitian menunjukkan tidak ada beda nyata antar perlakuan untuk kadar padatan yang mencapai sekitar $23-29 \%$ dan jumlah sel 6,32 - 6,56 $\log \mathrm{CFU} / \mathrm{g}$. Sedangkan nilai pH, warna dan pigmen larut air berbeda nyata antara perlakuan dan kontrol. Nilai ${ }^{\circ}$ hue perlakuan glisin dan kombinasi laurat-glisin masing-masing 16,11 dan 15,33 lebih rendah daripada kontrol $(22,76)$. Rasio $A_{500} n m / A_{400} n m$ tertinggi pada perlakuan kombinasi laurat-glisin dan kadar sitrinin terendah juga pada perlakuan kombinasi laurat-glisin. Temuan penelitian menunjukkan bahwa penambahan laurat atau glisin secara tunggal maupun kombinasinya dalam media beras untuk fermentasi Monascus purpureus JK9A terbukti dapat meningkatkan biosintesis pigmen merah (46,34\%) dan menurunkan kadar sitrinin hingga 49,97\%.
\end{abstract}

Kata kunci: Angkak; glisin; Monascus purpureus; laurat; pigmen; sitrinin; warna

\begin{abstract}
Angkak, commonly used for food colorant and flavor enhancers in oriental cuisine, is the result of fermentation by Monascus purpureus on steamed rice. In addition to producing pigments Monascus purpureus, Angkak also produces mycotoxins, citrinin, which is hepato-nephrotoxic. Biosynthesis of pigment and citrinin is following a polyketide synthase pathway and then subdivides to form pigment or citrinin. Fatty acids and amino acids are known to be the precursors of red pigment formers in their biosynthetic pathways. The purpose of this research was to know the effect of addition of lauric fatty acid and amino acid glycine on steamed rice substrate to the color characteristic and citrinin level by M. purpureus JK9A. The amount of lauric acid and glycine was respectively $0.5 \%$ and $1 \%(\mathrm{w} / \mathrm{w})$. Fermentation was carried out for 14 days and every two days the solids content of fermented products, $\mathrm{pH}$, number of cells, colors, pigments dissolved in water were measured. The level of citrinin was
\end{abstract}


tested at the end of the fermentation period ( $14^{\text {th }}$ day). There was no significant difference between treatments for the solids content of about $23 \square 29 \%$ and the number of cells $6.32-6.56 \log \mathrm{CFU} / \mathrm{g}$. While the pH value, color and water-soluble pigments were significantly different between treatment and control. The ${ }^{\circ}$ hue values of glycine and combination of lauric-glycine were 16.11 and 15.33, respectively, lower than controls (22.76). The highest $A_{500} \mathrm{~nm} / A_{400} \mathrm{~nm}$ ratio was in the combination treatment of lauric-glycine and the lowest levels of citrinin also in the treatment of lauric-glycine combination. This study noticed that the addition of lauric or glycine and its combination in rice media for Monascus purpureus JK9A fermentation proved to increase the biosynthesis of red pigment (46.34\%) and decrease citrinin level up to $49.97 \%$.

Keywords: Angkak; glycine; Monascus purpureus; lauric; pigment; citrinin; color

\section{PENDAHULUAN}

Angkak merupakan produk fermentasi Monascus purpureus pada media beras yang telah ditanak. Secara fisik angkak berbentuk butiran beras dan berwarna merah jingga sampai merah ungu. Selain $M$. purpureus, sering juga digunakan M. pilosus, M. ruber, M. anka maupun $M$. kaoliang untuk pembuatan angkak (Cheng dkk., 2010; Samsudin dan Abdullah, 2013). Angkak digunakan sebagai pewarna makanan dan penambah cita rasa masakan oriental, seperti sosis, red wine, keju Cina dan sebagai pengawet daging dan ikan (Blanc dkk., 1994; Erdoğrul dan Azirak, 2004; Pattanagul dkk., 2008). Dalam bidang kesehatan, angkak digunakan sebagai makanan suplemen untuk menurunkan kadar kolesterol darah. Angkak mengandung monacolin (mevinolin, lovastatin) yang menghambat produksi kolesterol melalui reaksi penghambatan kerja enzim HMGCoA reduktase yang mengaktivasi sintesis kolesterol (Erdoğrul dan Azirak, 2004). Sebagian masyarakat Asia, termasuk Indonesia menggunakan angkak untuk bumbu atau penyedap dalam masakan, pewarna makanan dan obat penurun kolesterol atau peningkat trombosit pada pasien demam berdarah. Walaupun demikian, spesies Monascus dapat menghasilkan sitrinin yang bersifat hepato-nephrotoksik (Blanc dkk., 1995) seperti halnya Aspergillus, Penicillium, terutama $P$. citrinum. Kadar sitrinin dalam angkak yang terdapat di pasaran berkisar 0,28-189,0 mg/kg (Gordon dkk., 2010; Samsudin dan Abdullah, 2013). Sifat toksik tersebut menjadi kendala dalam penerimaan angkak. Pembatasan kadar sitrinin dalam angkak berbeda-beda pada berbagai negara, seperti misalnya batsan kadar sitrinin di Taiwan adalah kurang dari 2 ppm, sedangkan di Jepang batasan kadar sitrinin adalah kurang dari 0,2 ppm (Lee dkk., 2010; Pattanagul dkk., 2007). Walaupun demikian Flajs dan Peraica (2009) menyatakan bahwa $\mathrm{LD}_{50}$ sitrinin pada tikus per oral adalah $50 \mathrm{mg} / \mathrm{kg}$ (berat badan), sementara (Chang dkk., 2011) menunjukkan bahwa sitrinin dengan konsentrasi hingga 12,5 ppm tidak bersifat sitotoksik terhadap kultur sel manusia. Namun demikian, kadar sitrinin paling tinggi yang tidak menyebabkan sakit (NOAEL) yang ditetapkan oleh European Food Safety Authority (EFSA) adalah $0,02 \mathrm{mg} / \mathrm{kg}$ berat badan per hari (EFSA, 2012).

Pembentukan senyawa sitrinin dipengaruhi oleh jenis mikroorganisme, media dan kondisi fermentasi. Hal ini terbukti bahwa Monascus ruber mulai menghasilkan sitrinin dalam media glukosa $(6,5 \mathrm{~g}$ per L) setelah 45 jam kultivasi (Hajjaj dkk., 1999), sedangkan Penicillium chrysogenum MTCC 5108 menghasilkan sitrinin pada jam ke tiga pertumbuhan yaitu menjelang fase logaritmik dan mencapai puncaknya pada jam ke 20 pada fase stasioner (Devi dkk., 2009). Penambahan asam-asam lemak jenuh rantai sedang (C6-C12) dapat menurunkan sintesis sitrinin pada Monascus ruber (Hajjaj dkk., 2000).

Monascus menghasilkan pigmen yang merupakan kelompok senyawa poliketida. Minimal terdapat enam jenis senyawa penyusun pigmen Monascus, yaitu: monascorubrin dan rubropunctatin yang berwarna jingga, monascin dan ankaflvin yang berwarna kuning, monascorubramin dan rubropunctamin yang berwarna merah. Dua jenis senyawa lain yang berwarna kuning dihasilkan oleh Monascus anka yang mengalami mutasi yaitu Xanthomonascin A dan B (Patakova, 2013; Wongjewboot dan Kongruang, 2011). Biosintesis pigmen melibatkan jalur poliketida sintase untuk membentuk poliketida kromofor dan biosintesis lipida untuk membentuk beta asam keto yang akan bereaksi dengan poliketida kromofor tersebut. Enzim poliketida sintase, salisilat hidroksilase dan amina oksidase merupakan rangkaian enzim yang terlibat dalam pembentukan poliketida kromofor. Hasil reaksi dengan asam keto akan membentuk senyawa antara dengan melibatkan enzim 3-0-asetiltransferase. Senyawa antara tersebut membentuk pigmen jingga melalui reaksi dehidrogenasi. Pigmen jingga dapat membentuk pigmen kuning dan merah melalui reaksi reduksi dan pembentukan basa Schiff (Huang dkk., 2017).

Pertumbuhan dan pembentukan metabolit sekunder Monascus secara umum dipengaruhi oleh faktor lingkungan, nutrisi dan cara fermentasi. 
Beberapa penelitian telah dilakukan untuk mengetahui sintesis pigmen Monascus pada substrat padat non beras yaitu dengan menggunakan biji nangka (Babitha dkk., 2007), adlay (Pattanagul dkk., 2008), biji durian (Srianta dkk., 2012), sorghum, manihot, colocasia, fagopyrum (Dikshit dan Tallapragada, 2011) dan kedelai hitam (Lee dkk., 2015) ataupun dengan substrat beras yang ditambah dengan sumber nitrogen organik dan anorganik (Vidyalakshmi dkk., 2009). Peneliti lain menggunakan media cair sintetik untuk menganalisis biosintesis pigmen Monascus dan membuktikan bahwa penambahan minyak kedelai memberikan hasil terbaik untuk pembentukan metabolit sekunder (Chung dkk., 2006) sedangkan minyak olive lebih cocok untuk pertumbuhan sel (Baneshi dkk., 2014). Pembentukan pigmen Monascus dapat dipengaruhi oleh stres lingkungan seperti suhu dan konsentrasi $\mathrm{NaCl}$ yang tinggi atau pun oleh konsentrasi glukosa yang tinggi. Produksi pigmen merah tertinggi adalah pada suhu $30^{\circ} \mathrm{C}$ (Babitha dkk., 2007; Chen dkk., 2015). Membran sel merupakan pembatas utama bagi mikroorganisme untuk mengatasi stres lingkungan, tidak hanya untuk penyerapan nutrisi tetapi juga untuk mengeluarkan produk-produk ekstraseluler. Permeabilitas dan fluiditas membran sel bergantung pada kejenuhan asam lemak penyusun membran sel. Asam lemak jenuh sebagai sumber karbon yang tinggi tetapi potensial oksidoreduktase rendah dapat memberikan produksi pigmen kuning ekstraseluler yang dapat larut dalam air dengan menggunakan Monascus ruber CGMCC 10910. Akhir-akhir ini telah diteliti biosintesis kelompok gen pigmen azaphilon dalam genom Monascus pilosus dan fungsi dari gen-gen penting dalam jalur biosintesis tersebut serta pengaruh konsentrasi glukosa yang tinggi pada fermentasi M. ruber CGMCC 10910 (Huang dkk., 2017). Pertumbuhan sel dan produksi lipida dianalisis untuk mengetahui hubungan produksi pigmen dan metabolisme lipida. Analisis dengan realtime quantitative PCR menunjukkan bahwa ekspresi dari kelompok gen pembentuk pigmen merupakan up-regulated pada kondisi stres glukosa yang tinggi. Hal ini mengindikasi bahwa stres glukosa yang tinggi dapat mengubah jalur biosintesis pigmen untuk mengakumulasi pigmen kuning dan menghasilkan pigmen intra dan ekstraseluer.

Penelitian ini bertujuan untuk mengetahui pengaruh penambahan asam lemak laurat dan asam amino glisin pada media beras dengan cara fermentasi padat terhadap produksi pigmen dan sitrinin oleh Monascus purpureus JK9A.

\section{METODE PENELITIAN}

\section{Bahan-bahan}

Beras IR64 (Sentra Ramos) diperoleh dari pasar lokal dalam kemasan $5 \mathrm{~kg}$ digunakan untuk substrat fermentasi. Beras IR64 mempunyai ciri-ciri berbentuk lonjong atau panjang dan tidak wangi. Bahan organik dan anorganik meliputi: asam lemak laurat (Merck), glisin (Merck), methanol (Merck, HPLC grade), asetonitril (Merck, HPLC grade), asam fosfat (p.a., Merck), etanol absolut (Merck), sitrinin standar (Sigma C 1017).

Kultur Monascus purpureus JK9A yang merupakan hasil isolasi dari angkak. Angkak diperoleh dari toko obat traditional di Jakarta, Indonesia. Isolasi dilakukan dengan menggunakan metode kultivasi langsung dengan desinfeksi permukaan. Isolat tersebut telah diidentifikasi secara molekuler dengan menggunakan primer ITS1ITS4. Hasil pencarian similaritas sekuen DNA dari isolat tersebut pada data base molekuler National Center for Biotechnology Information (NCBI) dengan Basic Local Alignment Search Tool (BLAST) menunjukkan bahwa isolat tersebut $99 \%$ identik dengan strain M. purpureus CBS 109,07 (AC KY635851). Kultur hasil isolasi disimpan dalam bentuk beku sebagai kultur stok dan disimpan dalam agar miring Potato Dextrose Agar (PDA) pada suhu $4^{\circ} \mathrm{C}$ dan disubkultur setiap bulan.

\section{Pembuatan angkak}

Pembuatan angkak dilakukan mengikuti metode (Chairote dkk., 2007) dengan modifikasi. Beras dicuci, ditiriskan dan dikeringkan dalam oven suhu $37^{\circ} \mathrm{C}$ sampai diperoleh berat awal beras. Lima puluh gram beras dimasukkan ke dalam labu Erlenmeyer $500 \mathrm{~mL}$ dan ditambah dengan asam lemak laurat $0,5 \%(b / b)$, asam amino glisin $1 \%(b / b)$ dan kombinasi laurat dan glisin secara terpisah. Selain itu dilakukan pula kontrol atau tanpa penambahan laurat maupun glisin. Dilakukan penambahan air hingga diperoleh kadar air $45 \%$ dan $\mathrm{pH}$ awal diatur pada $\mathrm{pH} 6,2 \pm 0,1$. Campuran dihomogenisasi dengan penggojogan secara manual kemudian disterilisasi dengan menggunakan autoklaf pada suhu $115^{\circ} \mathrm{C}$ selama 20 menit kemudian didiamkan hingga mencapai suhu ruang.

Pembuatan starter dilakukan dengan menyiapkan biakan Monascus purpureus JK9A pada media PDA agar miring berumur 9 hari. Ke dalam tabung biakan tersebut ditambahkan $10 \mathrm{~mL}$ akuades steril dan secara perlahan dilakukan pengerokan pada permukaan untuk memperoleh suspensi spora. Jumlah spora per $\mathrm{mL}$ dihitung dengan menggunakan haemocytometer. Berdasarkan hasil perhitungan jumlah spora per ml dari suspensi spora kemudian dilakukan pengenceran hingga 
diperoleh suspensi spora dengan jumlah spora $10^{6}$ per $\mathrm{ml}$. Suspensi spora tersebut digunakan sebagai starter. Jumlah starter yang ditambahkan adalah sebanyak $10 \%(\mathrm{v} / \mathrm{b})$ dari media fermentasi. Fermentasi dilakukan selama 14 hari, setiap 2 hari dilakukan pengujian kadar padatan produk, jumlah sel dan $\mathrm{pH}$. Produk fermentasi dikeringkan pada suhu $45{ }^{\circ} \mathrm{C}$ selama 14 jam dan dihancurkan dengan menggunakan penghancur biji untuk dilakukan pengujian terhadap warna, pigmen terlarut dalam air dan sitrinin (hanya produk fermentasi hari ke 14). Proses fermentasi tersebut dilakukan tiga kali ulangan dan pengujian untuk setiap parameter dilakukan triplo.

\section{Pengukuran padatan produk fermentasi}

Kadar padatan produkfermentasi ditentukan melalui penentuan kadar air bahan secara thermogravimetri. Ditimbang satu gram produk fermentasi di dalam botol timbang yang sudah diketahui berat konstannya, kemudian dikeringkan dalam oven, suhu $105^{\circ} \mathrm{C}$ sampai diperoleh berat konstan. Kadar padatan $(\%)=100 \%$ - kadar air bahan (\%).

\section{Penghitungan total sel Monascus}

Penghitungan total sel Monascus purpureus JK9A dilakukan menurut (Srianta dkk., 2012) dengan modifikasi. Sepuluh gram produk fermentasi dicampur dengan $90 \mathrm{~mL}$ larutan garam fisiologis ( $\mathrm{NaCl} \mathrm{0,85 \% )}$ steril dalam kantong plastik yang telah dipaparkan di bawah lampu UV, kemudian dimasukkan dalam stomach maker selama 2 menit. Satu $\mathrm{mL}$ filtrat dimasukkan ke dalam $9 \mathrm{~mL}$ larutan garam fisiologis dalam tabung dan dibuat pengenceran berseri sampai $10^{-4}$ dan $10^{-}$ 5. Sebanyak $1 \mathrm{~mL}$ dari setiap pengenceran dikultivasi pada media PDA dalam cawan Petri dan dibuat duplo. Inkubasi dilakukan selama 48 sampai 72 jam pada suhu $30{ }^{\circ} \mathrm{C}$ dan diikuti dengan penghitungan total koloni Monascus purpureus JK9A.

\section{Pengukuran warna}

Serbuk sampel diukur nilai warnanya, berupa lightness $\left(\mathrm{L}^{*}\right)$, redness $\left(\mathrm{a}^{*}\right)$ dan yellowness $\left(\mathrm{b}^{*}\right)$ (Teixeira dkk., 2013) dengan menggunakan chroma meter CR400 (Minolta Co. Ltd., Osaka, Japan). Nilai L*berkisar antara 0 (hitam) - 100 (putih), nilai a* menunjukkan arah warna merah (positif) dan hijau (negatif), nilai b* menunjukkan arah warna kuning (positif) dan biru (negatif). Nilai derajat hue $\left({ }^{\circ}\right.$ hue) yang menunjukkan nilai warna itu sendiri ditentukan sebagai $\left(\tan ^{-1} \mathrm{~b}^{*} / \mathrm{a}^{*}\right)$ dan nilai kroma ditentukan sebagai $\sqrt{ }\left(\mathrm{a}^{2}+\right.$ $\left.b^{2}\right)$ menunjukkan tingkat saturasi warna.

\section{Pengukuran pigmen}

Ekstraksi pigmen dilakukan dengan menggunakan akuades (Dikshit dan Tallapragada, 2011; Srianta dkk., 2012). Satu gram sampel dicampur dengan akuades pada perbandingan 1:20 dalam labu Erlenmeyer $100 \mathrm{~mL}$. Campuran dikocok dengan kecepatan putar 200 rpm selama 1 jam, kemudian diasaring dengan menggunakan kertas saring Whatman No. 1. Ekstrak disentrifugasi pada kecepatan $10.000 \mathrm{rpm}$ selama 5 menit dan diukur absorbansi pada $\lambda 400 \mathrm{~nm}, \lambda 470 \mathrm{~nm}$ dan $\lambda 500 \mathrm{~nm}$, masing-masing untuk pigmen kuning, jingga dan merah. Nilai absorbansi dikonversi ke nilai warna Absorbansi Unit per gram sampel (AU/g) melalui Persamaan 1.

$$
\begin{aligned}
& \text { Nilai warna }\left(\frac{A U}{g}\right) \\
& =\frac{\text { OD } x \text { volume ekstrak } x \text { faktor pengenceran }}{\text { berat sampel }(\text { gram })}
\end{aligned}
$$

\section{Pengukuran kadar sitrinin}

Ekstraksi sitrinin dilakukan menurut (Street dan Ma, 2007). Sebanyak $1 \mathrm{~g}$ serbuk angkak dicampur dengan $20 \mathrm{~mL}$ methanol $70 \%$ dalam tabung $50 \mathrm{~mL}$ kemudian dipanaskan pada suhu $65^{\circ} \mathrm{C}$ selama 30 menit. Campuran kemudian disaring dengan menggunakan kertas saring Whatman No. 1. Sebanyak $1 \mathrm{~mL}$ filtrat dikeringkan dengan menggunakan pengering vakum dan dilarutkan kembali dengan menggunakan metanol absolut. Ekstrak disaring dengan menggunakan membran filter 0,25 $\mu \mathrm{m}$. Pengenceran dilakukan bila luas area sampel belum terlingkup dalam seri luas area standar. Pembuatan standar sitrinin dilakukan dengan melarutkan $5 \mathrm{mg}$ sitrinin murni dalam $1 \mathrm{~mL}$ metanol sebagai larutan stok. Satu seri larutan standar dibuat dengan konsentrasi 25 ppb, 50 ppb, 100 ppb, 200 ppb, 300 ppb, 400 ppb, 500 $\mathrm{ppb}$, dan $600 \mathrm{ppb}$ dari larutan stok.

Pengujian sitrinin dilakukan dalam alat HPLC (Shimadzu 10A VP) menggunakan kolom C18 LiChropher 100 RP-18 (5 $\mu \mathrm{m})$ ukuran 125-4. Fase mobil menggunakan $0,1 \%$ asam fosfat $(A)$ dan asetonitril (B) dengan pengaturan larutan A pada $0-1$ menit: $60 \%, 1$ - 7 menit gradien linier $10 \%, 7$ - 9 menit: $10 \%, 9-$ 10 menit gradien linier: $60 \%$ dan $10-12$ menit: $60 \%$. Volume injeksi $100 \mu \mathrm{L}$, laju alir 1,0 mL/menit, detektor fluoresen diatur pada panjang gelombang $350 \mathrm{~nm}$ untuk eksitasi dan 500nm untuk emisi. Waktu retensi $\sim 5,7$ menit.

\section{Analisa statistik}

Data-data disajikan dalam bentuk hasil rata-rata $(n=3)$ dan \pm standar deviasi (SD) dari tiga ulangan 
fermentasi. Analisa statistik dilakukan dengan twofactor without replication (Anova) pada program Excel diikuti dengan uji LSD untuk menentukan perbedaan nyata antar perlakuan dengan selang kepercayaan $5 \%$.

\section{HASIL DAN PEMBAHASAN}

\section{Kadar padatan produk fermentasi, jumlah sel dan pH}

Produk fermentasi yang dimaksud di sini adalah hasil fermentasi pada hari-hari yang sudah ditetapkan. Pada awal fermentasi sampai dengan hari ke enam warna produk fermentasi tampak belum merata. Angkak memiliki warna merah merata di setiap butir beras sehingga sering disebut red rice fermented. Padatan kering produk fermentasi yang dinyatakan di sini merupakan campuran residu substrat dengan biomasa sel $M$. purpureus JK9A. Padatan kering produk fermentasi sampai pada hari ke 14 tidak berbeda nyata antar perlakuan (Gambar 1). Padatan kering menurun selama proses fermentasi, hingga pada akhir fermentasi atau hari ke 14 padatan kering produk fermentasi mencapai $23,07 \pm 1,80 \%-28,88 \pm 2,69 \%$. Rosenblitt dkk. (2000) menunjukkan bahwa pada hari ke 10 fermentasi angkak dengan menggunakan $M$. purpureus ATCC 16392 diperoleh hasil padatan kering sebesar $36,4 \%$. Pada penelitian ini diperoleh hasil yang sama pada fermentasi hari ke 10 yaitu $36,05 \pm 6,27 \%$ $40,65 \pm 6,11 \%$. Setelah hari ke 10 terjadi penurunan yang tajam pada padatan kering. Total penurunan padatan kering pada kontrol dan perlakuan dengan penambahan laurat dan glisin berkisar antara 51,03\% $-59,68 \%$. Selama proses fermentasi terjadi penurunan berat kering substrat akibat penggunaan substrat untuk pertumbuhan, produksi metabolit primer dan sekunder. Evolusi substrat menjadi produk-produk fermentasi ditentukan oleh kondisi lingkungan seperti $A w$, jenis

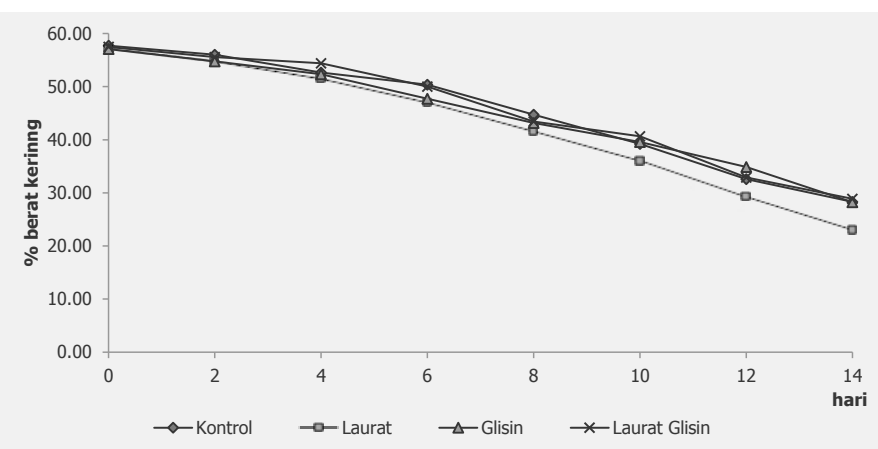

Gambar 1. Pengaruh penambahan laurat dan glisin terhadap persen berat kering residu substrat dan sel Monascus purpureus JK9A selama masa fermentasi karbon substrat, rasio $\mathrm{C} / \mathrm{N}$, strain Monascus (Chung dkk., 2006; Omanor dkk., 2008).

Secara umum tampak bahwa pertumbuhan M. purpureus JK9A paling baik pada media beras yang ditambah dengan asam amino glisin (Tabel 1) yang berbeda nyata dengan perlakuan lain pada hari ke 10 dan ke 12. Penambahan asam amino glisin dapat meningkatkan pertumbuhan $M$. Purpureus JK9A. (Vidyalakshmi dkk., 2009) juga menunjukkan pertumbuhan Monascus ruber lebih baik pada media beras yang ditambah dengan ekstrak khamir atau mono sodium glutamat (MSG) dibandingkan dalam media beras tanpa penambahan kedua bahan tersebut. Monosodium glutamat telah diketahui sebagai sumber nitrogen yang dapat memicu pertumbuhan dan pembentukan pigmen merah Monascus (Blanc dkk., 1995; Hajjaj dkk., 2012). Namun demikian, tidak semua asam amino akan berdampak sama seperti glisin, ekstrak khamir maupun MSG, terbukti bahwa Monascus ruber tidak tumbuh dengan baik pada media dengan asam amino triptofan maupun alanine (Hajjaj dkk., 2012).

Pengaruh asam lemak laurat pada media beras tampaknya sedikit memperlambat laju pertumbuhan $M$. purpureus JK9A. Hal ini tampak pada hari ke-14 jumlah sel pada media beras yang ditambah dengan asam lemak laurat masih menunjukkan peningkatan pertumbuhan sedangkan pada media yang lain pertumbuhan Monascus purpureus sudah menurun (Tabel 1). Perlambatan laju pertumbuhan juga ditunjukkan dengan kecilnya pertambahan jumlah sel selama proses fermentasi dibandingkan dengan perlakuan lain. Penambahan asam lemak laurat yang merupakan asam lemak jenuh rantai sedang akan mempengaruhi kondisi lingkungan, seperti menurunnya kelarutan oksigen dalam media fermentasi, akibatnya pertumbuhan sedikit terganggu. Perbedaan nyata jumlah sel antar perlakuan tampak pada hari ke 10 dan ke 12 proses fermentasi. Jumlah sel pada media beras yang ditambah dengan asam laurat relatif lebih rendah dibandingkan dengan kontrol atau perlakuan lainnya.

Selama proses fermentasi terjadi penurunan $\mathrm{pH}$ media, dari pH awal sekitar 6,2 menjadi 4,6 - 5,6 pada akhir fermentasi (Tabel 2), Nilai pH lingkungan fermentasi dipengaruhi oleh metabolit yang dikeluarkan oleh Monascus. Selama proses fermentasi Monascus mendegradasi pati dari beras menjadi maltosa dan glukosa. Degradasi lanjut dari senyawa-senyawa tersebut adalah pembentukan alkohol, asam malat dan asam sitrat yang menyebabkan kondisi media sedikt asam. Pada akhir fermentasi media yang ditambah asam lemak laurat atau glisin dan kombinasi keduanya mempunyai $\mathrm{pH}$ lebih tinggi daripada kontrol. Hal ini 
Tabel 1. Jumlah sel (log CFU/g) Monascus purpureus JK9A pada hari fermentasi

\begin{tabular}{llllll}
\hline Perlakuan & 4 hari & 8 hari & 10 hari & 12 hari & 14 hari \\
\hline Kontrol & $5,88 \pm 0,14^{\mathrm{a}}$ & $6,54 \pm 0,08^{\mathrm{a}}$ & $6,54 \pm 0,03^{\mathrm{b}}$ & $6,58 \pm 0,08^{\mathrm{b}}$ & $6,32 \pm 0,06^{\mathrm{a}}$ \\
Laurat & $5,77 \pm 0,17^{\mathrm{a}}$ & $6,46 \pm 0,11^{\mathrm{a}}$ & $6,41 \pm 0,17^{\mathrm{c}}$ & $6,38 \pm 0,14^{\mathrm{b}}$ & $6,40 \pm 0,14^{\mathrm{a}}$ \\
Glisin & $5,81 \pm 0,21^{\mathrm{a}}$ & $6,52 \pm 0,06^{\mathrm{a}}$ & $6,75 \pm 0,04^{\mathrm{a}}$ & $6,89 \pm 0,21^{\mathrm{a}}$ & $6,56 \pm 0,03^{\mathrm{a}}$ \\
Laurat-Glisin & $5,45 \pm 0,15^{\mathrm{a}}$ & $6,52 \pm 0,08^{\mathrm{a}}$ & $6,59 \pm 0,01^{\mathrm{b}}$ & $6,59 \pm 0,05^{\mathrm{b}}$ & $6,51 \pm 0,16^{\mathrm{a}}$ \\
\hline
\end{tabular}

Notasi yang berbeda pada kolom yang sama menunjukkan terdapat beda nyata antar perlakuan pada $p<0,05$

Tabel 2. Nilai pH selama fermentasi

\begin{tabular}{lllllll}
\hline & 4 hari & 6 hari & 8 hari & 10 hari & 12 hari & 14 hari $^{\circ}$ \\
\hline Kontrol & $4,48 \pm 0,14^{\mathrm{a}}$ & $4,59 \pm 0,06^{\mathrm{a}}$ & $4,36 \pm 0,07^{\mathrm{a}}$ & $4,27 \pm 0,08^{\mathrm{a}}$ & $4,27 \pm 0,07^{\mathrm{c}}$ & $4,61 \pm 0,09^{\mathrm{a}}$ \\
Laurat & $4,41 \pm 0,06^{\mathrm{a}}$ & $4,61 \pm 0,22^{\mathrm{a}}$ & $4,44 \pm 0,18^{\mathrm{a}}$ & $4,56 \pm 0,17^{\mathrm{a}}$ & $4,23 \pm 0,04^{\mathrm{c}}$ & $4,9 \pm 0,03^{\mathrm{b}}$ \\
Glisin & $4,83 \pm 0,02^{\mathrm{a}}$ & $4,96 \pm 0,19^{\mathrm{a}}$ & $4,83 \pm 0,14^{\mathrm{b}}$ & $4,98 \pm 0,10^{\mathrm{b}}$ & $5,34 \pm 0,02^{\mathrm{a}}$ & $5,59 \pm 0,10^{\mathrm{c}}$ \\
Laurat-Glisin & $4,80 \pm 0,28^{\mathrm{a}}$ & $4,82 \pm 0,05^{\mathrm{a}}$ & $4,84 \pm 0,21^{\mathrm{b}}$ & $4,98 \pm 0,23^{\mathrm{b}}$ & $5,24 \pm 0,02^{\mathrm{b}}$ & $5,59 \pm 0,06^{\mathrm{c}}$ \\
\hline
\end{tabular}

Huruf yang berbeda dalam satu kolom menunjukkan ada beda nyata pada $p<0,05$, kolom menunjukkan ada beda nyata $(p<0,05)$ pada hari fermentasi yang sama.

Tabel 3. Nilai warna angkak selama fermentasi

\begin{tabular}{|c|c|c|c|c|c|c|}
\hline Hari & Perlakuan & $\mathrm{L}^{*}$ & a* & $b^{*}$ & ${ }^{\circ}$ Hue & Chroma \\
\hline \multirow[t]{4}{*}{0} & Kontrol & $83,00 \pm 0,34$ & $4,07 \pm 0,13$ & $9,11 \pm 0,35$ & $65,93 \pm 0,55$ & $9,98 \pm 0,36$ \\
\hline & Laurat (L) & $84,81 \pm 0,47$ & $4,06 \pm 0,25$ & $8,78 \pm 0,09$ & $65,18 \pm 1,29$ & $9,68 \pm 0,16$ \\
\hline & Glisin (G) & $82,82 \pm 0,88$ & $4,14 \pm 0,18$ & $9,10 \pm 0,38$ & $65,54 \pm 0,44$ & $9,99 \pm 0,42$ \\
\hline & LG & $83,61 \pm 0,59$ & $4,17 \pm 0,18$ & $9,18 \pm 0,40$ & $65,58 \pm 0,59$ & $10,08 \pm 0,42$ \\
\hline \multirow[t]{4}{*}{8} & Kontrol & $35,46 \pm 1,02$ & $19,67 \pm 0,44$ & $8,47 \pm 1,45$ & $23,13 \pm 3,76^{\mathrm{ac}}$ & $21,46 \pm 0,70$ \\
\hline & Laurat (L) & $41,25 \pm 8,19$ & $20,96 \pm 3,02$ & $9,84 \pm 1,62$ & $25,09 \pm 0,86^{a}$ & $23,16 \pm 3,41$ \\
\hline & Glisin (G) & $37,39 \pm 5,17$ & $21,49 \pm 4,51$ & $7,26 \pm 1,78$ & $18,57 \pm 1,34^{b c d}$ & $22,69 \pm 4,82$ \\
\hline & LG & $36,38 \pm 3,67$ & $21,47 \pm 4,16$ & $6,74 \pm 1,48$ & $17,39 \pm 1,38^{\text {bd }}$ & $22,51 \pm 4,39$ \\
\hline \multirow[t]{4}{*}{10} & Kontrol & $34,54 \pm 1,16$ & $18,52 \pm 0,27$ & $7,87 \pm 1,74$ & $22,85 \pm 4,42$ & $20,18 \pm 0,86$ \\
\hline & Laurat (L) & $34,80 \pm 1,87$ & $19,41 \pm 2,83$ & $7,09 \pm 0,79$ & $20,30 \pm 3,06$ & $20,70 \pm 2,72$ \\
\hline & Glisin (G) & $33,35 \pm 1,12$ & $17,33 \pm 2,18$ & $5,47 \pm 0,05$ & $17,73 \pm 1,94$ & $18,18 \pm 2,09$ \\
\hline & LG & $33,15 \pm 1,11$ & $17,56 \pm 2,18$ & $5,38 \pm 0,41$ & $17,27 \pm 2,59$ & $18,39 \pm 2,07$ \\
\hline \multirow[t]{4}{*}{12} & Kontrol & $33,76 \pm 0,89^{a}$ & $16,77 \pm 0,85^{a}$ & $7,79 \pm 1,28^{a}$ & $24,71 \pm 2,74^{a}$ & $18,51 \pm 1,26^{a}$ \\
\hline & Laurat (L) & $32,95 \pm 0,86^{a}$ & $16,87 \pm 0,38^{a}$ & $6,10 \pm 1,73^{b}$ & $19,72 \pm 5,19^{b}$ & $18,01 \pm 0,68^{a}$ \\
\hline & Glisin (G) & $31,30 \pm 0,54^{b}$ & $14,12 \pm 0,65^{b}$ & $4,24 \pm 1,05^{c}$ & $16,54 \pm 3,26^{b}$ & $14,77 \pm 0,89^{b}$ \\
\hline & LG & $31,15 \pm 0,19^{b}$ & $14,52 \pm 0,72^{\mathbf{b}}$ & $4,06 \pm 0,52^{c}$ & $15,67 \pm 2,64^{b}$ & $15,08 \pm 0,56^{b}$ \\
\hline \multirow[t]{4}{*}{14} & Kontrol & $33,26 \pm 1,85$ & $16,27 \pm 2,00$ & $7,15 \pm 2,72$ & $22,76 \pm 5,97^{a}$ & $17,86 \pm 2,87$ \\
\hline & Laurat (L) & $31,89 \pm 1,04$ & $15,44 \pm 1,05$ & $5,42 \pm 1,49$ & $19,00 \pm 3,94^{a b}$ & $16,40 \pm 1,46$ \\
\hline & Glisin (G) & $30,80 \pm 0,63$ & $13,46 \pm 0,47$ & $3,91 \pm 0,86$ & $16,11 \pm 3,18^{b}$ & $14,04 \pm 0,61$ \\
\hline & LG & $31,16 \pm 0,46$ & $14,43 \pm 0,47$ & $3,97 \pm 0,91$ & $15,33 \pm 3,29^{b}$ & $14,99 \pm 0,54$ \\
\hline
\end{tabular}

Data merupakan nilai rata-rata dan SD dari tiga ulangan. Huruf yang berbeda dalam satu kolom menunjukkan ada beda nyata $(p<0,05)$ pada hari fermentasi yang sama 
disebabkan adanya unsur nitrogen tambahan dalam media yang berasal dari asam amino glisin. Asam amino dapat berfungsi sebagai buffer sehingga $\mathrm{pH}$ media dapat dipertahankan.

\section{Warna dan pigmen}

Nilai lightness $\left(L^{*}\right)$ produk fermentasi semakin menurun dengan bertambahnya waktu fermentasi pada semua perlakuan artinya tingkat kecerahan semakin rendah, sedangkan nilai redness ( $\left.a^{*}\right)$ semakin meningkat dan nilai yellowness ( $b^{*}$ ) menurun (Tabel 3).

Nilai $L^{*}$, a* dan $b^{*}$ tidak berbeda nyata antar perlakuan sampai dengan hari ke 10 masa fermentasi. Nilai ${ }^{\circ}$ hue dan chroma menunjukkan nilai dari warna dan saturasi warna. Warna angkak dipengaruhi oleh susunan pigmen yang dihasilkan oleh Monascus purpureus JK9A selama fermentasi. Penentuan nilai warna berdasarkan nilai $L^{*}, a^{*}, b^{*}$ menunjukkan perbedaan warna $\left({ }^{\circ}\right.$ hue) yang signifikan pada angkak atau produk fermentasi akhir (Tabel 3). Pada produk fermentasi hari ke 12 dan ke 14 menunjukkan perbedaan nilai ${ }^{\circ}$ hue yang signifikan pada perlakuan dibandingkan dengan kontrol. Penambahan asam lemak laurat dan asam amino glisin menjadikan ${ }^{\circ}$ hue lebih rendah daripada kontrol. Nilai ${ }^{\circ}$ hue yang semakin kecil (mengarah ke $0^{\circ}$ ) menunjukkan warna semakin merah. Hasil akhir fermentasi atau produk angkak dari substrat yang ditambah asam lemak laurat dan asam amino glisin berwarna lebih merah daripada kontrol karena nilai ${ }^{\circ}$ hue nya lebih rendah tetapi nilai saturasi warnanya tidak berbeda nyata antar perlakuan. Perlakuan penambahan asam lemak laurat dan asam amino glisin secara individu maupun secara kombinasi tidak memberikan perbedaan warna merah dan dibandingkan dengan kontrol meningkat sebesar 16,52 - 32,64\%. Warna angkak hasil fermentasi ini dapat dinyatakan sebagai merah gelap untuk kontrol dan merah sangat gelap untuk angkak hasil perlakuan penambahan asam lemak laurat dan asam amino glisin.

Pengamatan biosintesis pigmen ekstraseluler Monascus purpureus JK9A dilakukan dengan mengesktrak pigmen produk fermentasi dengan pelarut akuades dan perolehan pigmen dinyatakan dalam Absorbansi Unit per gram (AU/g) yang merupakan nilai absorbansi pada panjang gelombang $400 \mathrm{~nm}$ (pigmen kuning) dan $500 \mathrm{~nm}$ (pigmen merah). Hal ini dilakukan untuk mendekati pada aplikasi penggunaan pewarna angkak yang biasanya digunakan dengan mengekstrak menggunakan air. Nilai Absorbansi Unit pigmen kuning pada $\lambda 400 \mathrm{~nm}$ dan pigmen merah pada $\lambda 500 \mathrm{~nm}$ per gram bahan dari masing-masing perlakuan tampak pada Gambar 2. Absorbansi Unit per gram untuk pigmen kuning lebih tinggi dibandingkan untuk pigmen merah selama masa fermentasi untuk semua perlakuan.
Monascus purpureus menghasilkan pigmen monascin dan ankaflavin yang berwarna kuning dan pigmen monascorubramin dan rubropuntamin yang berwarna meah. Dalam aplikasinya untuk pewarna makanan yang banyak digunakan adalah warna merah. Hasil penelitian ini menunjukkan perlakuan penambahan asam amino glisin dan kombinasi laurat-glisin memberikan nilai $\mathrm{AU} / \mathrm{g}$ pada $\mathrm{A}_{500} \mathrm{~nm}$ (pigmen merah) lebih tiggi dari pada perlakuan penambahan asam lemak laurat dan kontrol (Gambar 2b). Penambahan asam amino glisin dapat meningkatkan biosintesis pigmen merah. Hasil ini terkait pula dengan nilai $\mathrm{pH}$ yang dicapai hingga akhir masa fermentasi, yaitu 5,59 lebih tinggi daripada nilai $\mathrm{pH}$ untuk kontrol $(4,6)$ dan media yang ditambah laurat $(4,9)$. Pembentukan pigmen merah dan stabilitas pigmen merah lebih baik pada $\mathrm{pH}$ netral sampai basa. Hal ini sesuai dengan penelitian yang dilakukan oleh Hajjaj dkk. (2012) yang menggunakan media cair sintetik yang menunjukkan asam-asam amino tertentu, termasuk glisin, dapat meningkatkan biosintesis pigmen merah. Secara umum absorbansi pigmen pada perlakuan penambahan asam lemak laurat lebih rendah daripada perlakuan lainnya akibat dari jumlah sel pada perlakuan penambahan asam lemak laurat lebih rendah.

Nuansa warna ekstrak angkak dinyatakan dalam nilai rasio absorbansi pada panjang gelombang 500 $\mathrm{nm}$ dengan $400 \mathrm{~nm}$. Pada fermentasi hari ke 4 nilai rasio tersebut lebih tinggi dibandingkan dengan harihari fermentasi selanjutnya (Tabel 4). Namun demikian warna produk fermentasi yang terbentuk pada hari ke
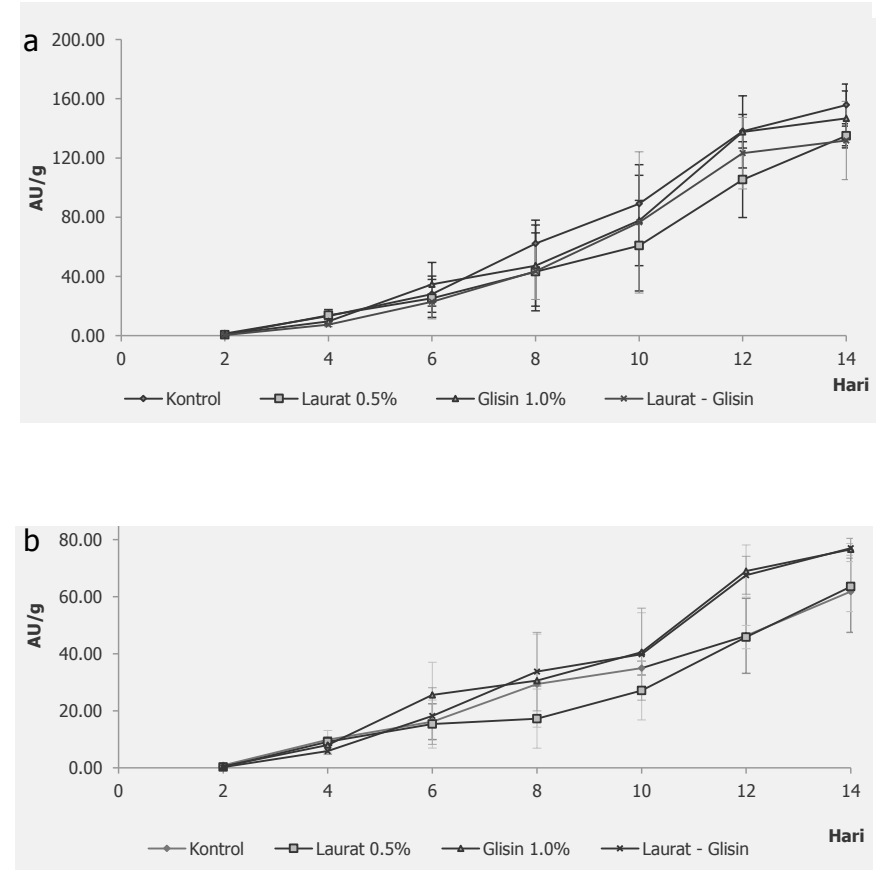

Gambar 2. Hasil absorbansi unit pigmen kuning/400 nm (a) dan merah/500nm (b) dalam ekstrak akuades. 
Tabel 4. Rasio nilai Abs.500 nm/400 nm

\begin{tabular}{lllllll}
\hline & 4 hari & 6 hari & 8 hari & 10 hari & 12 hari & 14 hari $^{\mathrm{a}}$ \\
\hline Kontrol & $0,75 \pm 0,09^{\mathrm{a}}$ & $0,60 \pm 0,06$ & $0,51 \pm 0,15^{\mathrm{bc}}$ & $0,43 \pm 0,13$ & $0,33 \pm 0,06^{\mathrm{b}}$ & $0,41 \pm 0,13^{\mathrm{b}}$ \\
Laurat & $0,64 \pm 0,09^{\mathrm{b}}$ & $0,58 \pm 0,07$ & $0,41 \pm 0,02^{\mathrm{b}}$ & $0,51 \pm 0,14$ & $0,46 \pm 0,12^{\mathrm{a}}$ & $0,48 \pm 0,09^{\mathrm{ab}}$ \\
Glisin & $0,82 \pm 0,08^{\mathrm{a}}$ & $0,73 \pm 0,03$ & $0,67 \pm 0,06^{\mathrm{ac}}$ & $0,54 \pm 0,05$ & $0,51 \pm 0,05^{\mathrm{a}}$ & $0,53 \pm 0,05^{\mathrm{ab}}$ \\
Laurat -Glsin & $0,80 \pm 0,09^{\mathrm{a}}$ & $0,75 \pm 0,17$ & $0,79 \pm 0,09^{\mathrm{a}}$ & $0,59 \pm 0,13$ & $0,56 \pm 0,06^{\mathrm{a}}$ & $0,60 \pm 0,09^{\mathrm{a}}$ \\
\hline
\end{tabular}

Huruf yang berbeda pada kolom yang sama menunjukkan ada beda nyata $(p<0,05)$ antar perlakuan pada hari yang sama

4 tersebut masih rendah. Hal ini menunjukkan bahwa pada hari ke 4 fermentasi Monascus purpureus JK9A sekalipun membentuk pigmen merah tetapi masih menggunakan media untuk pertumbuhannya. Pigmen merah terbentuk melalui pembentukan basa Schiff yang melibatkan asimilasi bahan nitrogen. Pembentukan pigmen jingga melibatkan reaksi esterifikasi kromofor dengan beta keto asil pada biosintesis asam lemak. Selanjutnya pigmen jingga akan mengalami reaksi reduksi membentuk pigmen kuning atau pigmen merah melalui asimilasi.

Berdasarkan ke empat perlakuan yang digunakan dalam penelitian ini ternyata penambahan asam lemak laurat memberikan biosintesis pigmen merah terendah. Tabel 4 menunjukkan terdapat peningkatan warna merah yang tidak signifikan $(17,07 \%)$ antara kontrol dengan media beras yang ditambah asam lemak laurat, demikian juga dengan penambahan asam amino glisin tidak memberikan peningkatan warna merah yang signifikan $(29,27 \%)$. Namun penambahan kombinasi asam lemak laurat dan asam amino glisin meningkatkan warna merah secara nyata dibandingkan dengan kontrol (46,34\%). Penambahan asam lemak laurat meningkatkan jumlah sumber karbon. Biosintesis pigmen akan membentuk warna jingga dan kuning. Namun demikian pembentukan pigmen kuning pada perlakuan asam lemak laurat tidak berbeda nyata dengan perlakuan lainnya dan cenderung lebih rendah. Oleh sebab itu dalam penelitian ini yang terjadi adalah pembentukan pigmen pada perlakuan dengan asam lemak laurat lebih rendah akibat dari jumlah sel yang lebih rendah.

\section{Kadar sitrinin}

Pengukuran kadar sitrinin hanya dilakukan pada hari ke 14 masa fermentasi atau akhir fermentasi yang memberikan warna merah maksimum. Penambahan asam lemak laurat dan asam amino glisin mengakibatkan pembentukan sitrinin menurun (Gambar 3).

Dibandingkan dengan kontrol, rata-rata penurunan kadar sitrinin sebesar 28,40 $\pm 11,74 \%$ jika di dalam substrat ditambah dengan asam lemak laurat, sedangkan jika ditambah dengan asam amino glisin penurunan terjadi lebih besar, yaitu 39,72 $\pm 3,20 \%$. Penambahan kedua senyawa prekursor pembentuk warna tersebut dapat menurunkan kadar sitrinin hampir $50 \%$, yaitu $49,97 \pm 0,89 \%$. Hal ini sesuai dengan hasil penelitian (Hajjaj dkk., 2012) yang menunjukkan bahwa pemberian asam amino glisin dapat meningkatkan nilai pigmen dan menurunkan kadar sitrinin pada fermentasi dengan menggunakan media sintetik.

Nilai sitrinin angkak yang diperoleh dari perlakuan kombinasi penambahan asam lemak laurat dan asam amino glisin adalah sebesar 24,24 $\pm 3,45 \mathrm{ppm}$. Bila mengacu pada aturan yang ditetapkan oleh EFSA yakni bahwa kadar sitrinin paling tinggi yang tidak menyebabkan sakit (NOAEL) adalah 0,02 $\mathrm{mg} / \mathrm{kg}$ berat badan per hari (European Food Safety Authority, EFSA), 2012) maka angkak tersebut aman dikonsumsi sampai $50 \mathrm{~g}$ per hari oleh orang dewasa dengan berat badan $70 \mathrm{~kg}$. Namun bila mengacu pada aturan yang ditetapkan oleh pemerintah Taiwan atau Jepang bahwa kadar sitrinin dalam angkak maksimum 2 ppm atau 0,2 ppm, kadar sitrinin yang diperoleh dalam penelitian ini jauh lebih tinggi dari ketetapan yang diberlakukan oleh kedua negara tersebut.

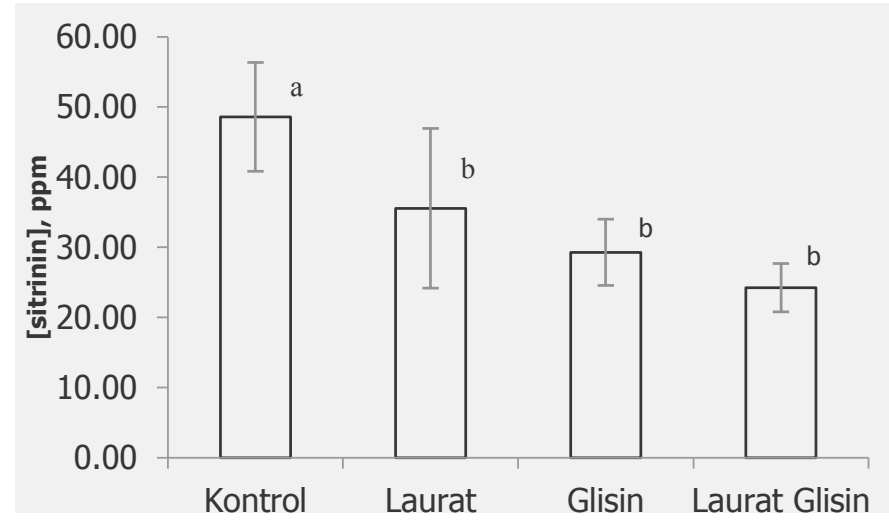

Gambar 3. Kadar sitrinin angkak yang diperoleh dari substrat yang diperkaya dengan laurat dan glisin dengan lama fermentasi 14 hari. Garis vertikal merupakan standar deviasi (SD) dari tiga kali ulangan. Huruf yang berbeda menunjukkan terdapat perbedaan nyata pada $p<0,05$. 
Penurunan kadar sitrinin disebabkan oleh terjadinya penghambatan biosintesis sitrinin. Penambahan asam lemak laurat mengakibatkan biosintesis pigmen lebih terpacu. Biosintesis pigmen membutuhkan asam lemak rantai sedang, yang juga dihasilkan oleh kapang. Asam lemak berikatan dengan struktur kromofor menghasilkan pigmen monascorubrin atau rubropunctatin melalui reaksi trans-esterifikasi. Pada fermentasi dengan menggunakan Monascus ruber dalam media cair yang ditambah asam lemak laurat menghasilkan sitrinin yang lebih rendah dibandingkan dengan penambahan asam lemak jenuh rantai sedang lainnya (Hajjaj dkk., 2000).

Pembentukan pigmen berlangsung dalam sitoplasma. Penambahan asam lemak rantai sedang menyebabkan kapang melakukan sekresi enzim lipase yang akan mendegradasi asam lemak sehingga asam lemak dapat masuk ke dalam sel. Pengangkutan hasil degradasi lipase terjadi melalui transport aktif sehingga Monascus perlu menyediakan sejumlah energi ATP untuk dapat mengangkutnya. Namun demikian, ketika sudah berada di dalam sel akan memicu pembentukan pigmen. Sedangkan asam amino glisin merupakan asam amino bebas yang lebih mudah masuk ke membran sel. Glisin bersifat larut dalam air, dan sebagai asam amino lebih mudah menerobos membran sel sehingga penambahan glisin lebih menurunkan biositesis sitrinin.

\section{KESIMPULAN}

Penambahan asam lemak laurat atau glisin secara tunggal maupun kombinasinya dalam media beras untuk fermentasi Monascus purpureus JK9A terbukti dapat meningkatkan biosintesis pigmen merah dan menurunkan kadar sitrinin. Walaupun penurunan kadar sitrinin dalam media beras yang ditambah dengan asam lemak laurat dan asam amino glisin belum mencapai di bawah 2 ppm, namun penelitian ini dapat memberi informasi bahwa asam amino glisin mampu meningkatkan biosintesis pigmen merah larut air dan menurunkan sitrinin angkak. Perlu diupayakan pemilihan jenis asam amino lain atau sumber protein lain yang dapat diaplikasikan pada media beras untuk mendapatkan angkak yang rendah sitrinin hingga kurang dari $2 \mathrm{ppm}$ selain pemilihan strain Monascus purpureus.

\section{UCAPAN TERIMA KASIH}

Terima kasih disampaikan kepada Universitas Katolik Widya Mandala Surabaya yang telah memberi dana penelitian yang merupakan bagian dari dana studi lanjut program doktor.

\section{DAFTAR PUSTAKA}

Babitha, S., Soccol, C. R., \& Pandey, A. (2007). Solid-state fermentation for the production of Monascus pigments from jackfruit seed. Bioresource Technology, 98(8): 1554-1560.

Baneshi, F., Azizi, M., Saberi, M., \& Farsi, M. (2014). Evaluation of $\mathrm{pH}$, carbon source and temperature effect on the pigments production by Monascus purpureus in a liquid culture using response surface methodology. Int.J.Curr. Microbiol.App.Sci, 3(10): 905-911.

Blanc, P. J., Laussac, J. P., Le Bars, J., Le Bars, P., Loret, M. O., Pareilleux, A., \& Goma, G. (1995). Characterization of monascidin-A from Monascus as citrinin. Int. J. of Food Microbiology 27: 201-213.

Blanc, P. J., Loret, M. O., Santerre, A. L., Pareilleux, A., Prome, D., Prome, J. C., \& Goma, G. (1994). Pigments of Monascus. Journal of Food Science (4): 5-8.

Chairote, E., Griangsak, C., Wongpornchai, S., \& Lumyong, S. (2007). Preparation of red yeast rice using various Thai glutinous rice and Monascus purpureus CMU001 isolated from commercial Chinese red yeast. Kmitl Science and Technology Journal, 7: 28-37.

Chang, C. H., Yu, F. Y., Wu, T. S., Wang, L. T., dan Liu, B. H. (2011). Mycotoxin citrinin induced cell cycle G2/M arrest and numerical chromosomal aberration associated with disruption of microtubule formation in human cells. Toxicological Sciences, 119(1): 84-92.

Chen, G., Shi, K., Song, D., Quan, L., dan Wu, Z. (2015). The pigment characteristics and productivity shifting in high cell density culture of Monascus anka mycelia. BMC Biotechnology, 15(1): 1-9.

Cheng, M. J., Wu, M. Der, Yang, P. S., Chen, J. J., Chen, I. S., Chen, Y. L., dan Yuan, G. F. (2010). Secondary metabolites isolated from the fungus monascus kaoliangfermented rice. Journal of the Chilean Chemical Society, 55(1): 107-110.

Chung, C. C., Chen, H. H., dan Hsieh, P. C. (2006). Application of the taguchi method to optimize, 30: 241-254.

Devi, P., D'Souza, L., Kamat, T., Rodrigues, C., dan Naik, C. G. (2009). Batch culture fermentation of Penicillium chrysogenum and a report on the isolation, purification, identification and antibiotic activity of citrinin. Indian Journal of Marine Sciences, 38(1): 38-44.

Dikshit, R., dan Tallapragada, P. (2011). Monascus purpureus: A potential source for natural pigment production. J. Microbiol. Biotech. Res, 1(4): 164-174.

Erdoğrul, Ö., dan Sebile Azirak. (2004). Review of the studies on the red yeast rice (Monascus purpureus). Turkish Electronic Journal of Biotechnology, 2: 37-49. 
European Food Safety Authority (EFSA). (2012). Scientific Opinion on the risks for public and animal health related to the presence of citrinin in food and feed. The EFSA Journal, 10(3): 1-82.

Flajs, D., dan Peraica, M. (2009). Toxicological properties of citrinin. Arhiv Za Higijenu Rada i Toksikologiju, 60(4): 457-464.

Gordon, R. Y., Cooperman, T., Obermeyer, W., dan Becker, D. J. (2010). Marked variability of monacolin levels in commercial red yeast rice products: Buyer beware! Archives of Internal Medicine, 170(19): 1722-1727.

Hajjaj, H., François, J. M., Goma, G., dan Blanc, P. J. (2012). Effect of amino acids on red pigments and citrinin production in Monascus ruber. Journal of Food Science, 77(3): 156-159.

Hajjaj, H., Klaébé, A., Goma, G., Philippe, J., Barbier, E., dan François, J. (2000). Medium-chain fatty acids affect citrinin production in the filamentous fungus Monascus ruber Applied and Enviromental Microbiology, 66(3): 1120-1125.

Hajjaj, H., Klaébé, A., Loret, M. O., Goma, G., Blanc, P. J., dan François, J. (1999). Biosynthetic pathway of citrinin in the filamentous fungus Monascus ruber as revealed by $13 \mathrm{C}$ nuclear magnetic resonance. Applied and Environmental Microbiology, 65(1): 311-314.

Huang, T., Tan, H., Lu, F., Chen, G., dan Wu, Z. (2017). Changing oxidoreduction potential to improve watersoluble yellow pigment production with Monascus ruber CGMCC 10910. Microbial Cell Factories, 16(1): 1-12.

Lee, C. H., Lee, C. L., dan Pan, T. M. (2010). A 90-D Toxicity study of monascus-fermented products including high citrinin level. Journal of Food Science, 75(5): T91-T97

Lee, Y. S., Choi, B. K., Lee, H. J., Lee, D. R., Cheng, J., Lee, W. K., dan Suh, J. W. (2015). Monascus pilosus-fermented black soybean inhibits lipid accumulation in adipocytes and in high-fat diet-induced obese mice. Asian Pacific Journal of Tropical Medicine, 8(4): 276-282.

Omanor, I. B., Eziashi, E. I., dan Adekunle, A. A. (2008). Carbon nutrition in relation to growth of three Monascus species isolated from decaying date fruits. Journal of Microbiology, (2): 153-155.
Patakova, P. (2013). Monascus secondary metabolites: Production and biological activity. Journal of Industrial Microbiology and Biotechnology, 40(2): 169-181.

Pattanagul, P., Pinthong, R., dan Phianmongkhol, A. (2007). Review of angkak production (Monascus purpureus). Chiang Mai J. Sci., 34(3): 319-328.

Pattanagul, P., Pinthong, R., Phianmongkhol, A., dan Tharatha, S. (2008). Mevinolin, citrinin and pigments of adlay angkak fermented by Monascus sp. International Journal of Food Microbiology, 126(1-2): 20-23.

Rosenblitt, A., Agosin, E., Delgado, J., dan Pérez-Correa, R. (2000). Solid substrate fermentation of Monascus purpureus: Growth, carbon balance, and consistency analysis. Biotechnology Progress, 16(2): 152-162.

Samsudin, N. I. P., dan Abdullah, N. (2013). A preliminary survey on the occurrence of mycotoxigenic fungi and mycotoxins contaminating red rice at consumer level in Selangor, Malaysia. Mycotoxin Research, 29(2): 89-96.

Srianta, I., Hendrawan, B., Kusumawati, N., dan Blanc, P. J. (2012). Study on durian seed as a new substrate for Angkak production. International Food Research Journal, 19(3): 941-945.

Street, P., dan Ma, U. S. A. (2007). CitriTest TM HPLC Instruction Manual.

Teixeira, C. C. C., Teixeira, G. A., dan Freitas, L. A. P. (2013). Improving the production and CIELAB* color parameters of Monascus ruber pigments using a fractional factorial design. Asian Journal of Biomedical \& Pharmaceutical Sciences, 2(15): 62-68.

Vidyalakshmi, R., Paranthaman, R., Murugesh, S., dan Singaravadivel, K. (2009). Stimulation of Monascus pigments by intervention of different nitrogen sources. Global Journal of Biotechnology \& Biochemistry, 4(1): 25-28.

Wongjewboot, I., dan Kongruang, S. (2011). pH stability of ultrasonic Thai isolated Monascus purpureus pigments. International Journal of Bioscience, Biochemistry and Bioinformatics, 1(1): 79-83. 